\title{
Analysis of Information Technology Maturity Level Based on Po and Ai Domains Using Cobit 4.1 At the Department of Informatics Engineering
}

\author{
Agus Prayitno $^{1}$, Fransiskus Xaverius Manggau ${ }^{2}$, Nilfred Patawaran ${ }^{3}$ \\ Informatics Engineering Department \\ Universitas Musamus \\ Merauke, Indonesia \\ 1'agusprayitno@unmus.ac.id, ${ }^{2}$ fransiskus @unmus.ac.id, ${ }^{3}$ nilfred@unmus.ac.id
}

\begin{abstract}
Technology for communication in business processes by companies or organizations, in the form of services, is increasingly felt the benefits that ultimately encourage the use of information technology, with a guarantee of good service management becoming a fundamental need. Nowadays the Informatics Engineering Department has utilized such information technology, therefore in the user information technology, there are still problems requiring a management model that can be used as a reference, in accordance with the company's strategy and objectives, and can be used to overcome the problems occurring in agencies. COBIT is a representative and comprehensive governance standard model for the entire IT process. Based on that, then this research will design an IT management model for the Merauke Informatics Engineering Department using the COBIT framework. The COBIT framework identifies IT processes in four main domains: Planning and Organization (PO), Acquisition and Implementation (AI) domains, Delivery and Support (DS), and Monitoring and Evaluate $(M E)$. The PO domain includes strategies and tactics, as well as attention to identifying the ways of IT in giving its best contribution to the achievement of business objectives. The AI domain includes the realization, implementation, and integration of IT strategies, into business processes. The DS domain deals with the delivery and support of the IT services. The ME domain includes supervision of all controls applied to each IT process. The results of this research indicate that the $P O$ domain is at level 2 (repeatable but intuitive), and the AI domain is at level 1 (initial / Ad-hoc), so that Information Technology in the Informatics Engineering Department of Merauke is still below the expected level of maturity, at level 3 (Define).
\end{abstract}

Keywords- COBIT 4.1; Maturity Level; Planning and Organizing; Acquisition and Implementation

\section{INTRODUCTION}

The role of technology for communication in business processes, by companies or organizations in the form of services, is increasingly felt the benefits that ultimately encourage the use of information technology, with the guarantee of good service management becoming a fundamental need. On the other hand, the government, as a regulator, provides a benchmark for company implementation policies related to service and security management, especially for public service providers [1].
The use of service standards and security in guiding business processes becomes one of the solutions, but the organization has its own difficulties in understanding the extent to which these standards have been implemented, especially when the organization implements more than one standards. This is possible because the focus of standard is considered to be less broad in scope to meet all IT management needs [2].

Merauke Informatics Engineering is a department that utilizes the website as a means of supporting information. This system aims to provide actual information anytime and anywhere, students can find out information through the website, but the use of the website is not optimal yet. It can be seen that only a few students use the website as an information service, due to the absence of socialization about information services found in the Merauke Informatics Engineering Department. So that the maturity level of website usage is not known by the Merauke Informatics Engineering Department.

Analysis of the maturity level of website usage can be used as a reference in making recommendations for improvements to optimize website usage. This analysis combines model maturity with the COBIT framework (Control Objectives for Information and Related Technologies) [3].

In conducting IT management, the Merauke Informatics Engineering Department requires a management model that can be used as a reference, in accordance with the company's strategy and objectives, and can be used to overcome the problems that occur in the company. Control Objectives for Information and Related Technology (COBIT) is a representative and comprehensive model of governance standards, which covers planning, implementation, operations, and supervision of the entire IT process. Based on this, this research will design an IT management model for the Merauke Informatics Engineering Department using the COBIT framework.

The COBIT framework identifies IT processes in four main domains, namely Planning and Organization (PO), Acquisition and Implementation (AI) domains, Delivery and Support (DS), and Monitoring and Evaluate (ME). The PO domain includes strategies and tactics, as well as attention to identify the ways of IT for its best contribution to the achievement of business objectives. The AI domain includes the realization, 
implementation, and integration of IT strategies into business processes. The DS domain deals with the delivery and support of IT services. The ME domain includes supervision of all controls applied to each IT process [4].

The preparation of the IT management model in Merauke Informatics Engineering is carried out on the PO \& AI domain. The selection of these two domains is adjusted to the problems and needs of Merauke's Informatics Engineering in managing IT, including strategies and tactics, as well as attentions to the identification of IT ways, realization, implementation, and integration of IT strategies in providing the best contribution. Based on the analysis on the Merauke Information Engineering IT Master Plan document, it can be identified that the problems and IT needs of the Maharaja Ban Jakarta are currently in the PO \& AI domain of the COBIT framework [5].

Based on this, an analysis of the application of the Information Technology system is carried out, by formulating the following problems. How the evaluation of the implementation of IT Governance in Merauke Informatics Engineering today is. What the level of maturity (IT maturity level) of IT governance conducted in Merauke Informatics Engineering is. What solution can be given to improving the implementation of IT Governance in Merauke Informatics Engineering is.

\section{METHOD}

Research is a process of finding solutions to problems that exist through the stages of study and analysis of influential factors or variables. As a process of study and analysis, of course research must follow the principles of research so that the results can be accounted scientifically [6].

In this research, the data was collected from respondents using a questionnaire. This research was designed and developed as a research which states an explanatory relationship. The sampling method used in this study is purposive sampling technique, which is a sample taken with a specific purpose or goal [7].

\section{A. Data Collection}

The initial stage of data collection is by looking for literature studies related to maturity level analysis with the COBIT framework (Control Objectives for Information and Related Technologies) that can measure the achievement and readiness in an assessment index to help organizations find out the security management of their services.

\section{B. Interview}

Interview with the Head of Department. Case study of the Informatics Engineering Department. The aim is to get information related to the website that has been applied in the Merauke Informatics Engineering Department.

\section{Data Analysis}

From the data obtained, both through the results of interviews and from the results of data collection, then the data were analyzed the level of maturity level of IT service security on the Informatics Engineering Department website.

\section{Process/Concept}

In this research, researchers chose the Chairman of the IT Department, the Secretary of the IT Department, and the Head of the IT Department. With reference to this sample, the object of the study population is the information system manager majoring in IT. The number of respondents in the study amounted to four people, can be seen in the following table 1:

TABLE I. QUESTIONNAIRE RESPONDENT

\begin{tabular}{|c|l|c|}
\hline No & \multicolumn{1}{|c|}{ Respondent } & Amount \\
\hline 1 & Chairman of IT Department & 1 \\
\hline 2 & Secretary of IT Department & 1 \\
\hline 3 & Head of IT Department & 1 \\
\hline \multicolumn{2}{|c|}{ Total } & 3 \\
\hline
\end{tabular}

This study uses instrumentation in the form of a questionnaire. The questionnaire statement was developed based on the number of statements or statements at each maturity level in each control objective, in the Plan and Organization (PO) domain and the Aquire and Implement (AI) domain. The total statement in the PO domain is 291 statements and the total statement in the AI domain is 196 statements. So, the total statement in the questionnaire is 487 statements. The number of statements in the domain can be seen in Table 2 and Table 3 below:

TABLE II. The Number OF STATEMENTS IN THE Plan AND ORGANIZATION DOMAIN (PO)

\begin{tabular}{|c|c|c|c|c|c|c|c|}
\hline \multirow[t]{2}{*}{ Domain } & \multicolumn{6}{|c|}{ Level of Maturity } & \multirow{2}{*}{$\begin{array}{c}\text { Total of } \\
\text { Statement }\end{array}$} \\
\hline & 0 & 1 & 2 & 3 & 4 & 5 & \\
\hline $\begin{array}{l}\text { PO1 - Defining } \\
\text { IT Strategy } \\
\text { Planning }\end{array}$ & 2 & 3 & 2 & 4 & 5 & 5 & 21 \\
\hline $\begin{array}{l}\text { PO2 - Defining } \\
\text { Information } \\
\text { Architecture }\end{array}$ & 3 & 5 & 6 & 5 & 6 & 7 & 32 \\
\hline $\begin{array}{l}\text { PO3 - Setting } \\
\text { Ways of } \\
\text { Technology }\end{array}$ & 2 & 4 & 6 & 7 & 7 & 8 & 34 \\
\hline $\begin{array}{l}\text { PO4 - Defining } \\
\text { Processes, } \\
\text { Organizations, } \\
\text { and IT Relations }\end{array}$ & 2 & 3 & 2 & 7 & 8 & 6 & 28 \\
\hline $\begin{array}{l}\text { PO5 - Managing } \\
\text { IT Investment }\end{array}$ & 2 & 5 & 4 & 7 & 6 & 6 & 30 \\
\hline $\begin{array}{l}\text { PO6 - } \\
\text { Communication } \\
\text { Management } \\
\text { Aims and } \\
\text { Direction }\end{array}$ & 2 & 3 & 4 & 5 & 3 & 3 & 20 \\
\hline $\begin{array}{l}\text { PO7 - Managing } \\
\text { IT Human } \\
\text { Resource }\end{array}$ & 2 & 4 & 3 & 5 & 6 & 7 & 27 \\
\hline $\begin{array}{l}\text { PO8 - Managing } \\
\text { Values }\end{array}$ & 3 & 3 & 2 & 4 & 9 & 5 & 26 \\
\hline $\begin{array}{l}\text { PO9 - Scoring } \\
\text { and Managing IT } \\
\text { Risks }\end{array}$ & 3 & 4 & 5 & 7 & 8 & 9 & 36 \\
\hline $\begin{array}{l}\text { PO10-- } \\
\text { Managing } \\
\text { Projects }\end{array}$ & 1 & 8 & 6 & 8 & 9 & 5 & 37 \\
\hline Total & 22 & 42 & 40 & 59 & 67 & 61 & 291 \\
\hline
\end{tabular}


TABLE III. THE NUMBER OF STATEMENTS IN THE ACQUIRE AND IMPLEMENT DOMAIN (AI)

\begin{tabular}{|c|c|c|c|c|c|c|c|}
\hline \multirow[t]{2}{*}{ Domain } & \multicolumn{6}{|c|}{ Level of Maturity } & \multirow{2}{*}{$\begin{array}{c}\text { Total of } \\
\text { Statement }\end{array}$} \\
\hline & 0 & 1 & 2 & 3 & 4 & 5 & \\
\hline $\begin{array}{l}\text { AI } 1- \\
\text { Identifying } \\
\text { Automatic } \\
\text { Solutions }\end{array}$ & 2 & 4 & 5 & 3 & 6 & 6 & 26 \\
\hline $\begin{array}{l}\text { AI 2- } \\
\text { Defining the } \\
\text { IT Planning } \\
\text { Strategy }\end{array}$ & 2 & 4 & 4 & 5 & 6 & 6 & 27 \\
\hline $\begin{array}{l}\text { AI } 3- \\
\text { Gaining and } \\
\text { Treating } \\
\text { Technology } \\
\text { Infrastructure }\end{array}$ & 2 & 5 & 5 & 5 & 5 & 5 & 27 \\
\hline $\begin{array}{l}\text { AI } 4- \\
\text { Sustaining } \\
\text { Operation } \\
\text { and } \\
\text { Application }\end{array}$ & 2 & 6 & 5 & 7 & 8 & 5 & 33 \\
\hline $\begin{array}{l}\text { AI 5 - } \\
\text { Getting IT } \\
\text { Human } \\
\text { Resource }\end{array}$ & 2 & 5 & 6 & 7 & 8 & 7 & 35 \\
\hline $\begin{array}{l}\text { AI 6- } \\
\text { Obtaining } \\
\text { Changes }\end{array}$ & 2 & 4 & 2 & 5 & 5 & 5 & 23 \\
\hline $\begin{array}{l}\text { AI 7- } \\
\text { Installing } \\
\text { and } \\
\text { Admitting } \\
\text { Changes and } \\
\text { Solutions } \\
\end{array}$ & 2 & 3 & 3 & 4 & 7 & 6 & 25 \\
\hline Total & 14 & 31 & 30 & 36 & 45 & 40 & 196 \\
\hline
\end{tabular}

This research uses data analysis techniques quantitatively and descriptively. Descriptive Analysis is used to find out how current IT governance in the Informatics Engineering Department is, and how solutions can be given to improving the implementation of information technology governance in the Merauke Informatics Engineering Department.

The Quantitative analysis technique is using Microsoft Excel spreadsheet to process all answers, and explain the formulation of the problem of maturity level of Information Technology Governance, conducted in the Merauke Informatics Engineering Department. The data obtained from the respondents will be processed using an average calculation to get the average maturity level and radar chart, which then can be seen that the level of maturity in the institution is whether at a high or low maturity level, and the maturity level of the Informatics Engineering Department is still at a low level of maturity, at level 3, so it does not match the expected level of maturity [8].

\section{RESUlT AND DISCUSSION}

The COBIT maturity level questionnaire distributed to respondents is used to calculate the level of IT governance maturity at the Informatics Engineering Department recently. This questionnaire is made based on the maturity level criteria set out in the COBIT 4.1 framework for PO \& AI domains. The scale used in this questionnaire is the Guttman scale; whilst in the questionnaire, 2 (two) answer choices are provided $\mathrm{Y}$ (Yes) and $\mathrm{N}$ (No). In the calculation, the answer $\mathrm{Y}$ (Yes) is converted to a value of 1 , and the answer $\mathrm{N}$ (No) is converted to a value of 0 . The software used in this maturity level calculation is Microsoft Excel. After all the questionnaire results are input on the table, then the maturity level of each process is calculated in the Planning and Organization domain (10 processes), and Acquisition and Implementation (7 processes) in the questionnaire distributed to each respondent. The maturity level of each process from 3 respondents is then searched for the average, and the average results will be the maturity level or maturity level of each IT process.

The results of the recapitulation of the maturity level for the PO \& AI domain with the predetermined process can be seen in Table 4 and Table 5.

TABLE IV. The MATURITy LEVEls RECAPITULATION OF PLAN AND ORGANIZATION DOMAIN (PO)

\begin{tabular}{|l|c|c|c|}
\hline \multicolumn{1}{|c|}{$\begin{array}{c}\text { Domain } \\
\text { Process }\end{array}$} & $\begin{array}{c}\text { Current } \\
\text { Maturity }\end{array}$ & $\begin{array}{c}\text { Expected } \\
\text { Maturity }\end{array}$ & Maturity Level \\
\hline $\begin{array}{l}\text { PO1 - Defining } \\
\text { IT Strategy } \\
\text { Planning }\end{array}$ & 1,65 & 3 & 2 \\
\hline $\begin{array}{l}\text { PO2 - Defining } \\
\text { Information } \\
\text { Architecture }\end{array}$ & 2,05 & 3 & 2 \\
\hline $\begin{array}{l}\text { PO3 - } \\
\text { Determining } \\
\text { Ways of } \\
\text { Technology }\end{array}$ & 2,20 & 3 & 2 \\
\hline $\begin{array}{l}\text { PO4-Defining } \\
\text { Process, } \\
\text { Organizations, } \\
\text { and IT Relations }\end{array}$ & 2,15 & 3 & 2 \\
\hline $\begin{array}{l}\text { PO5 - Managing } \\
\text { IT Investment }\end{array}$ & 1,82 & 3 & 2 \\
\hline $\begin{array}{l}\text { PO6 - } \\
\text { Communication } \\
\text { Management } \\
\text { Aims and } \\
\text { Direction }\end{array}$ & 1,63 & 3 & 2 \\
\hline $\begin{array}{l}\text { PO7 - Managing } \\
\text { IT Human } \\
\text { Resource }\end{array}$ & 1,68 & 3 & 2 \\
\hline $\begin{array}{l}\text { PO8 - Managing } \\
\text { Values }\end{array}$ & 1,68 & 3 & \\
\hline $\begin{array}{l}\text { PO9 - Managing } \\
\text { and Scoring IT } \\
\text { Risks }\end{array}$ & & 3 & \\
\hline $\begin{array}{l}\text { PO10 - } \\
\text { Managing } \\
\text { Projects }\end{array}$ & & 3 & \\
\hline
\end{tabular}


TABLE V. THE MATURITY LEVELS RECAPITULATION OF ACQUIRE AND IMPLEMENT DOMAIN (AI)

\begin{tabular}{|l|c|c|c|}
\hline \multicolumn{1}{|c|}{$\begin{array}{c}\text { Domain } \\
\text { Process }\end{array}$} & $\begin{array}{c}\text { Current } \\
\text { Maturity }\end{array}$ & $\begin{array}{c}\text { Expected } \\
\text { Maturity }\end{array}$ & Maturity Level \\
\hline $\begin{array}{l}\text { AI 1 - } \\
\text { Identifying } \\
\text { Automatic } \\
\text { Solution }\end{array}$ & 0,54 & 3 & 1 \\
\hline $\begin{array}{l}\text { AI 2 - Defining } \\
\text { IT Strategy } \\
\text { Planning }\end{array}$ & 1,00 & 3 & 1 \\
\hline $\begin{array}{l}\text { AI 3 - Getting } \\
\text { and Treating } \\
\text { Technology } \\
\text { Infrastructure }\end{array}$ & 1,60 & 3 & 1 \\
\hline $\begin{array}{l}\text { AI 4- } \\
\text { Sustaining } \\
\text { Operation and } \\
\text { Application }\end{array}$ & 0,81 & 3 & 1 \\
\hline $\begin{array}{l}\text { AI 5 - Getting } \\
\text { IT Human } \\
\text { Resource }\end{array}$ & 0,50 & 3 & 1 \\
\hline $\begin{array}{l}\text { AI 6 - Getting } \\
\text { Changes }\end{array}$ & 1,00 & 3 & 1 \\
\hline $\begin{array}{l}\text { AI 7 - Installing } \\
\text { and Admitting } \\
\text { Solutions and } \\
\text { Changes }\end{array}$ & 1,00 & 3 & \\
\hline
\end{tabular}

From the results of the maturity level calculation, where the level of maturity that is the reference in this research is at level 3 (Define). Based on the results of calculations that have been done, it can be obtained that the level of maturity of IT in the Informatics Engineering Department of Merauke for PO Domains is on level 2 averagely, and for AI domains at level 1 averagely, means that current IT Management on the Department Merauke's Informatics Engineering needs to be improved because it is still below level 3 .

The assessment of the maturity level of each control objective or IT process in the PO and AI domains, refers to COBIT maturity level version 4.1 with assessment index criteria, can be seen in Table 6 below:

TABLE VI. CRITERIA FOR VALUE INDEX ON MATURITy LEVEL COBIT VERSION 4.1

\begin{tabular}{|l|l|}
\hline $0-0.55$ & Non-Existent \\
\hline $0.51-1.50$ & Initial/Ad Hoc \\
\hline $1.51-2.50$ & Repeatable But Invinitve \\
\hline $2.51-3.50$ & Defined Process \\
\hline $3.51-4.50$ & Managed and Measurable \\
\hline $4.51-5.00$ & Optimized \\
\hline
\end{tabular}

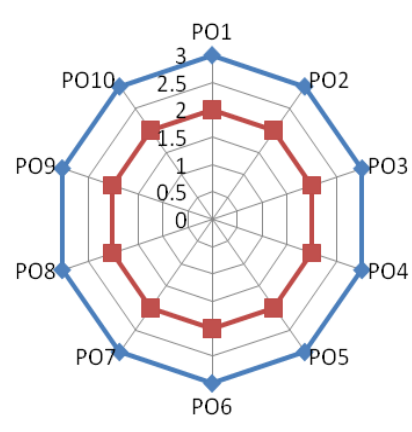

$\sim$ Expected Maturity

$\rightarrow$ Current Maturity

Fig. 1. Current Maturity Level vs Expected Maturity Level on Domain Planing and Organization

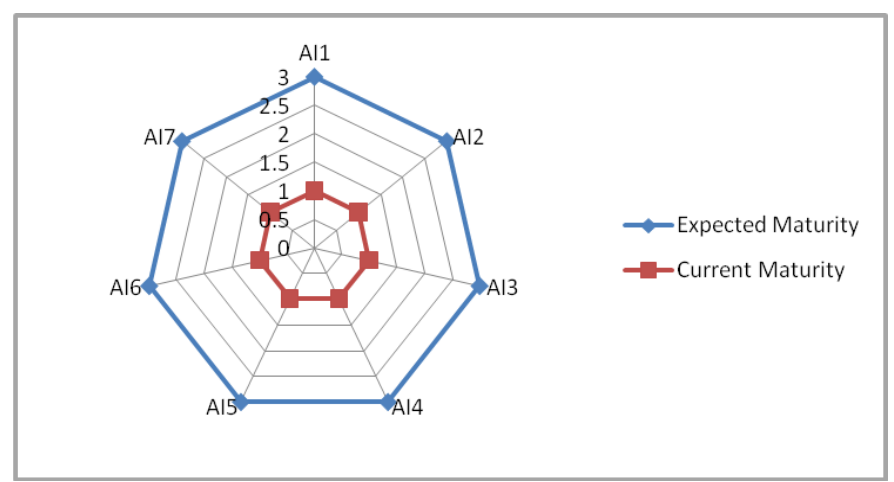

Fig. 2. Current Maturity Level vs Expected Maturity Level on Domain Acquisition and Implementation

\section{A. Domain Planning and Organization (PO)}

In the PO domain, it can be seen in the 10 processes studied averagely are at level 2 below the expected level of maturity at level 3 (Define). With the highest level of maturity PO3 Determining the ways of technology. There is no technology planning that has the potential to create business opportunities, the existing infrastructure planning is not adapted to the strategic and tactical planning of IT, there is no technology forum so that it can regulate technology standards and practices based on business relevance. While PO8 - Managing Values is the smallest level of maturity in the PO domain. At this level it is known that the company's risk management policy has not determined, when and how to carry out a risk assessment, risk management does not follow the established and documented process; risk management training is not yet available to all staff.

\section{B. Domain Acquisition and Implementation (AI)}

In the AI domain, there are 7 processes examined averagely at level 1 (Initial). With the highest level of maturity in AI3 Obtain and maintain Technology Infrastructure. There has been no formal change management procedure to deal with it. There is no process to determine, improve, assess, and validate changes that appear not following the amended change process.

In this research, the entire process is still below the expected level of maturity at level 3 (Define). Therefore, to reach the level of maturity at level 3 needs to be prioritized. Super priority, to go to level 3 , the process of AI1, AI2, AI3, AI4, AI5, AI6, AI7 is given a super priority where the gap that 
is found with the level of maturity looks far below level 3 . Priority, the process of PO1, PO2, PO3, PO4, PO5, PO6, PO7, $\mathrm{PO} 8, \mathrm{PO}$, PO10, get priority to increase the level of maturity reaching level 3.

Every process that exists in the Planning and Organization (PO) and Acquisition and Implementation (AI) domains is entirely below level 3, the current maturity level. It can be said that the overall IT process in the PO domain has been carried out, but it is still reactive, in accordance with the sudden needs that exist, without being preceded by prior planning. And if the documentation process has been carried out, it is still very weak, so it cannot be used as a reference if something similar happens. The gap in maturity level found in the control objectives in the PO and AI domains can be overcome by the Informatics Engineering Department by referring to COBIT version 4 literatures especially on Maturity levels.

\section{Analysis of Desired Maturity Levels}

Government in Indonesia has various references in carrying out the tasks and functions of each agency. Each government agency has a RENSTRA as a reference in the implementation of a period of 4 years, while agencies related to community services have a Standard Operational Procedure (SOP) as a reference for carrying out their duties [9].

The Informatics Engineering Department has a RENSTRA which will be used as a benchmark for the success of performance fulfillment, and can be used as a reference for the authors to analyze the level of IT governance maturity.

\section{Recommendation of IT Governance}

The governance design is the final result of governance based on the identification of the IT process, the results of the maturity assessment, observations, and interviews. These governance recommendations will later serve as a basis for establishing the Informatics Engineering Department's strategic plan the following year, to implement IT governance according to CoBIT standards. Recommendations for the Planning and Organizing (PO) section, as follows:

- Preparing an adequate superstructure, transferring knowledge from experts to other staff through training or courses covering fields that use information technology in business processes.

- Conducting periodic evaluations of IT staff, and assigning tasks and responsibilities according to the expertise of each staff.

- Creating and documenting policies and procedures on the entire IT process and governance, formally as standard guidelines for all users, while still paying attention to risk management.

Recommended Acquisition and Implementation (AI), as follows:

- Making plans for infrastructure changes for the future.

- Cooperating with parties that have met the standards set by the government.

- Testing all procurement such as software, data quality, and operational activities.
- Preparing staff to be ready to adapt if there is a new system or software update.

\section{CONCLUSION}

Based on the results of research conducted at the Merauke Informatics Engineering Department by looking at 10 PO Domain Processes and 7 Domain Processes of AI COBIT 4.1 Framework, including evaluation of the implementation of IT governance in the Informatics Engineering Department in Merauke, currently at level 2 for PO domains and levels 1 for AI domain. The level of maturity of IT governance carried out in the Merauke Informatics Engineering Department is: PO domain is at level 2 (repeatable but intuitive) where the process has developed, the same procedure is carried out by different people, and there is no formal communication or training on standard procedures and the responsibility is handed over, there is high trust in the ability of the individual, so mistakes are very likely. While the AI domain is at level 1 (initial / Ad-hoc) where there is known event and is seen as problem that needs to be handled by the company, there is no standard, the approach taken is ad-hoc, tends to be resolved by individuals, the carried-out data processing is not organized yet.

Improvement of IT governance in the Merauke Informatics Engineering Department, for the PO and AI domains, is by increasing the level of maturity at level 3 (Define Process) based on the mission, vision, objectives, and development direction of the Merauke Informatics Engineering Department, where procedure is standardized and documented, and communicated through training.

In order to produce the right recommendation, it requires deep understanding and knowledge; the questionnaire does not provide $100 \%$ conditions on information technology governance in an agency because the understanding of the statements on the questionnaire can be responded differently by each person. To produce recommendations, good coordination is also needed to truly ensure short, medium, and long-term targets.

\section{ACKNOWLEDGMENT}

We thank Universitas Musamus for facilities, supports, and publications

\section{REFERENCES}

[1] D.K. Informasi, Panduan Penerapan Tata Kelola Keamanan Informasi Bagi Penyelenggara Pelayanan Publik, Jakarta: Kominfo, 2011.

[2] M. Gehrmann, "Combining ITIL : COBIT and ISO/IEC27002 for Structuring Comprehensive Information Technology for Management in Organizations," Navus: Revista de Gestão e Tecnologia, vol. 2, pp. 66-77, 2012.

[3] F. Sakinah and B. Setiawan, "Indeks Penilaian Kematangan (Maturity) Manajemen Keamanan Layanan TI,” J. Tek. ITS, vol. 3, pp. A222A227, 2014.

[4] R.R. Peterson, "Integration Strategies and Tactics for Information Technology Governance dalam Strategies for Information Technology Governance," Strateg. Inf. Idea Technol. Gov., Igi Global, pp. 37-38, 2004.

[5] I. Carolina, "Pengukuran Tingkat Maturity Tata Kelola TI Berdasarkan Domain PO dan AI Menggunakan COBIT 4.1”. J. Sist. Inf., vol. 4, pp. 23-32, 2018. 
[6] U. Sekaran and R. Bougie, Research Methods for Business: a Skill Building Approach, John Wiley \& Sons Inc., 2000.

[7] E.D. Septiandra, "Analisis Tata Kelola Teknologi Informasi (It Governance) pada Dinas Sosial Ketenagakerjaan dan Transmigrasi Kota Salatiga Menggunakan Cobit 4.1," unpublished.

[8] IT Governance Institute, CobIT (4,1th ed): Framework, Control Objectives, Management Guidelines and Maturity Model, USA: ITGI, 2007.

[9] G. Manorang, "Audit TataKelola Teknologi Informasi Pada PTPN 13 Pontianak Menggunakan Framework COBIT," J. Ilmu-Ilmu Sos. : Socioscientia, vol. 4, pp. 97-114, 2012. 